\title{
Analysis of cis-Regulatory Elements in the 5' Flanking Region of the Drosophila melanogaster Choline Acetyltransferase Gene
}

\author{
Toshihiro Kitamoto, Kazuo Ikeda, and Paul M. Salvaterra \\ Division of Neurosciences, Beckman Research Institute of the City of Hope, Duarte, California 91010
}

\begin{abstract}
We have analyzed the cis-regulatory elements in the $5^{\prime}$ flanking region of the Drosophila choline acetyltransferase gene (ChAT, E.C.2.3.1.6). DNA fragments were fused to the Escherichia coli lacZ reporter gene and introduced into the Drosophlla germ line by P-element-mediated transformation. A $7.4 \mathrm{~kb} 5^{\prime}$ tlanking sequence directed $\beta$-galactosidase expression in the adult optic lobes and other well-defined CNS structures with a pattern very similar to the distribution of endogenous ChAT protein. In contrast, the proximal $3.3 \mathrm{~kb}$ and $1.2 \mathrm{~kb}$ of $5^{\prime}$ flanking DNA directed lacZ expression in only selected subsets of the structures seen with the $7.4 \mathrm{~kb}$ lac $Z$ construct. Our results indicate that both qualitative and quantitative regulatory elements are present in the $5^{\prime}$ flanking DNA and that these elements distinguish various subsets of cholinergic neurons. We have also fused the same $5^{\prime}$ flanking DNA sequences to wild-type ChAT CDNA and used these constructs to transform Chats mutant flies. Not only the $7.4 \mathrm{~kb}$ cDNA construct, but also the 3.3 and $1.2 \mathrm{~kb}$ constructs, rescued Chat from temperature-dependent paralysis and adult lethality, indicating that the regulatory information in any of these genomlc tragments can drive sufficient wild-type ChAT expression to overcome these mutant phenotypes.
\end{abstract}

Regulation of gene expression in the nervous system results in collections of phenotypically characteristic neurons. Among the many examples of gene regulation that have functional significance for nervous system organization are the macromolecules involved in the synthesis of neurotransmitters. These macromolecules determine the particular chemical signals uscd in spccific intercellular communication pathways. Many immunocytochemical studies have established the regularly patterned organization of neurotransmitter phenotypes among different species and brain regions. Using probes to neurotransmitterspecific gene products, such as antibodies to ChAT (acetyl-CoA: choline- $O$-acetyltransferase, EC 2.3.1.6), it has been possible to map the positions of cholinergic neurons in the brains of many different species (see, e.g., Salvaterra and Vaughn, 1989). ChAT is the biosynthetic enzyme responsible for $\mathrm{ACh}$ production, and

Received Sept. 5, 1991; revised Nov. 19, 1991; accepted Nov. 25, 1991.

We thank Rodney Williamson and Verenice Gutierrez for their expert advice and help. This work was supported by grants from NIH-NINDS and the Beckman Research Institute.

Correspondence should be addressed to Paul M. Salvaterra, Division of Neurosciences, Beckman Research Institute of the City of Hope, 1450 East Duarte Road, Duarte, CA 91010.

Copyright (C) 1992 Society for Neuroscience $0270-6474 / 92 / 121628-12 \$ 05.00 / 0$ cells that express this enzyme are thought to make and use ACh as their primary neurotransmitter substance. Since the primary function of neurons is intercellular communication, it is important to match ChAT expression patterns with properly endowed follower cells. Several different types of cholinergic receptors have been described that are clearly different gene products, but all are thought to respond to the $\mathrm{ACh}$ message sent by their respective presynaptic cholinergic neurons.

The molecular logic of how the brain specifies and maintains ncurotransmitter phenotypes is poorly understood. Neurotransmitter specification has been shown to involve the action of both genetic and epigenetic factors. Studies using Caenorhabditis elegans have emphasized the role of early commitment to specific cell lincages (Sulston and Horwitz, 1977). In other systems, such as peripheral sympathetic ganglia, regulation by soluble factors has been shown to be important (see, e.g., Patterson, 1978; Yamamori et al., 1989). More recent studies have demonstrated a role for cell-cell interactions (Schotzinger and Landis, 1990). All of these factors are thought to converge ultimately on transcriptional regulation of the genes for neurotransmitterspecific macromolecules. The specific transcriptional factors that act at appropriate cis-DNA regulatory sequences in the regulatory region of the ChAT gene would thus result in specifying that a particular neuron become a cholinergic neuron. Identifying the cis-regulatory elements necessary for ChAT gene expression should provide important clues about the regulatory signals necessary for cholinergic phenotype selection. In addition, the same or other cis-DNA elements may also be important for the maintenance or even plasticity of cholinergic neurons.

We are using Drosophila melanogaster as a model system to study the regulation of ChAT expression. In Drosophila, genes and their cis-regulatory elements can be characterized by a number of genetic and molecular approaches. Cloned DNA can be readily altered in vitro and then reliably integrated into the germ line via P-element vectors (Rubin and Spradling, 1982), allowing correlations of molecular information with both structural and behavioral phenomena observed in intact animals. A single ChAT gene has been identified in Drosophila and mapped to the right arm of the third chromosome (Greenspan, 1980). Several mutant alleles are available for ChAT, and a number of physiological and behavioral phenotypes have been described for some of the mutants (Greenspan, 1980; Gorczyca and Hall, 1984). Many of the ChAT alleles are late embryonic lethals, indicating the critical importance of the cholinergic neurotransmitter system. Two temperature-sensitive alleles have also been isolated for Drosophila ChAT allowing intrinsic enzyme activity to be conditionally modified by temperature (Greenspan, 1980). 
Drosophila ChAT has also been well studied biochemically. We have previously purified and characterized ChAT from adult Drosophila heads (Slemmon et al., 1982), and the corresponding cDNA has been cloned and sequenced (Itoh et al., 1986; Sugihara et al., 1990). The expression of Drosophila ChAT is subject to both temporal and spatial regulation. The enzyme, as well as its mRNA, is present at all but the earliest developmental stages (Dewhurst et al., 1970; Carbini et al., 1990). Changes in ChAT activity, and mRNA levels, also occur developmentally and in a parallel manner (Carbini et al., 1990), suggesting that transcription is a major regulatory feature of ChAT expression. The enzyme expression pattern, determined by immunocytochemistry, is broadly distributed, in characteristically defined subsets of neuronal processes present in both the PNS and CNS of Drosophila during several stages of development (Buchner et al., 1986; Gorczyca and Hall, 1987; Ikeda and Salvaterra, 1989). In situ hybridization studies localizing ChAT mRNA are consistent with the protein distribution pattern described for the adult cephalic ganglion (Barber et al., 1989), indicating that transcriptional control is a major feature for determining ChAT distribution. Several in vitro observations suggest that both translational (Sugihara et al., 1990) and posttranslational (Slemmon, 1989) mechanisms may also play a role in regulating Drosophila ChAT expression.

Many nervous system-specific genes have been cloned from Drosophila, and in some cases the cis-DNA regulatory elements, responsible for nervous system-specific expression of the genes, have also been identified. A particularly good example of defined DNA motifs has been obtained by Hirsh and his colleagues for the dopa decarboxylase (Ddc) gene (Scholnick et al., 1986; Bray et al., 1988, 1989; Johonson et al., 1989). Individual regulatory motifs have been identified for both CNS-specific and cell typespecific expression. The Ddc neuron-specific regulatory elements are composed of the proximal promoter region of the gene and a distal enhancer. The proximal promoter region contains one defined regulatory element required for expression of Ddc in the CNS. The distal enhancer is required for appropriate cell-specific expression of Ddc in the CNS (Beall and Hirsh, 1987). Two neuron-specific regulatory elements have been defined within this enhancer; one is required for Ddc expression in 5-HT-containing neurons of the larval ventral ganglion, and the other is for Ddc expression in the medial class of dopaminergic neurons (Johnson et al., 1989). Some of the transcription factors that bind these regulatory elements have also been identified and cloned (Bray et al., 1988; Johnson and Hirsh, 1990).

Recently we have cloned the genomic DNA for Drosophila ChAT including approximately $10 \mathrm{~kb}$ of $5^{\prime}$ and $3^{\prime}$ flanking sequence (Sugihara et al., 1991). The structural gene spans more than $26 \mathrm{~kb}$ of DNA and is composed of eight exons with a long $(>16 \mathrm{~kb}$ ) first intron (Sugihara et al., 1991). In this report, DNA fragments with varying amounts of the 5 ' flanking sequence were fused to the $l a c Z$ reporter gene and introduced into the Drosophila genome using P-element-mediated germ line transformation. The histochemical localization of $\beta$-galactosidase expression was used to assay the ability of putative cis-regulatory elements to drive expression of $l a c Z$ in adult cephalic ganglia relative to the known ChAT protein and mRNA distribution patterns. The same putative $c i s$-regulatory elements were also fused to a wild-type Drosophila ChAT cDNA and used to transform animals carrying a temperature-sensitive ChAT allele. These transformant lines were examined for phenotypic rescue and wild-type ChAT enzyme production.

\section{Materials and Methods}

Stocks and culture Drosophila melanogaster. Flies were kept on cornmeal/molasses/agar medium, supplemented with dry active yeast in half-pint milk bottles with cardboard stoppers or cylindrical vials with cotton stoppers. They were grown in a $25^{\circ} \mathrm{C}$ incubator on a $12 \mathrm{hr}$ light/ $12 \mathrm{hr}$ dark cycle.

DNA manipulations and P-element-mediated germ line transformation. DNA manipulations were performed according to standard procedures described in Sambrook et al. (1989). P-element-mediated germ line transformation of Drosophila melanogaster was performed as described in Rubin and Spradling (1982). The fusion-gene plasmids (described below) were dissolved in $0.1 \mathrm{~mm}$ potassium phosphate buffer (pH 7.8) containing $5 \mathrm{mM} \mathrm{KCl}$ at $0.8 \mathrm{mg} / \mathrm{ml}$ with $0.1 \mathrm{mg} / \mathrm{ml}$ helper plasmid: $\mathrm{p} \pi 24.7 \mathrm{wc}$ (Karess and Rubin, 1984) or puchs $\Delta 2-3$ (Halfen, personal communication). The recipients for lac $Z$ constructs and ChAT cDNA constructs (see below) were white and white; $C h a^{\prime s l}$, respectively. Linkage analysis of the inserted $P$-elements was carried out by examining their segregation from second and third chromosomes marked with $C y$ and $D l$, respectively.

Southern blot analysis of genomic DNA was carried out to confirm single-copy insertions of P-elements. One line carrying the $1.2 \mathrm{~kb}-l a c Z$ construct (line 2) had two P-elements on the third chromosome. One line carrying the $0 \mathrm{~kb}-\mathrm{ChAT}$ (line 1 ) had two P-elements.

LacZ constructs. Four genomic fragments having varying amounts of ' 5 ' flanking sequences of the ChAT gene were inserted into the P-element transformation vector pCaSpeR-AUG- $\beta$-gal (Thummel et al. 1988). The $7.4 \mathrm{~kb}$ genomic fragment isolated from the pEMBL Drosophila clonc gD517 (Sugihara et al., 1991) by digcstion with BamHI was subcloned into pBluescript $\mathrm{KS}(+/-)$ (Stratagene). The $7.4 \mathrm{~kb}$ and the $3.3 \mathrm{~kb}$ fragments were excised from the plasmid as a BamHI fragment and an EcoRI/BamHI fragment, respectively, and inserted into the polylinker site of the pCaSpeR-AUG- $\beta$-gal. For the $1.2 \mathrm{~kb}$ fragment pBluescript $\mathrm{KS}(+/-)$ containing the $7.4 \mathrm{~kb}$ fragment was first digested with AccI and then end filled with Klenow enzyme and ligated with EcoRI linker. The $1.2 \mathrm{~kb}$ fragment was excised as an EcoRI/BamHI fragment and inserted into the polylinker site of the pCaSpeR-AUG- $\beta$ gal. The $0.5 \mathrm{~kb}$ fragment was first subcloned into pBluescribe (Stratagene) as a Sacl/BamHI fragment, which was excised from pBluescribe as an EcoRI/BamHI fragment and inserted into the polylinker site of the pCaSpeR-AUG- $\beta$-gal.

Wild-type ChAT cDNA constructs. The $2.4 \mathrm{~kb}$ Drosophila ChAT cDNA, which contains the entire protein coding sequence (Itoh et al., 1986), was subcloned into pGEN-7Zf $(+)$ (Promega) as an EcoRI fragment and excised as a BamHI/Xbal fragment. This fragment was used to replace the lac $Z$ portion of pCaSpeR-AUG- $\beta$-gal (Thummel et al., 1988) constructs described above.

$X$-gal histochemical staining. Flies homozygous for the introduced P-element were frozen in O.T.C. compound, cut into $8-\mu \mathrm{m}$-thick sections, and loaded on agar-coated slides. After air drying, they were fixed with $0.1 \%$ glutaraldehyde in $100 \mathrm{~mm}$ phosphate buffer (pH 7.4) for 5 $\mathrm{min}$ at room temperature and then rinsed in $100 \mathrm{~mm}$ Tris- $\mathrm{HCl}$ (pH 7.4). The sections were submerged in X-gal staining buffer (10 mM Tris- $\mathrm{HCl}$, pH 7.4, $5 \mathrm{~mm}$ potassium ferricyanide, $5 \mathrm{~mm}$ potassium ferrocyanide, $150 \mathrm{~mm} \mathrm{NaCl}, 2 \mathrm{~mm} \mathrm{MgCl}, 0.2 \%$ X-gal) at $37^{\circ} \mathrm{C}$ for $3-24 \mathrm{hr}$. After rinsing in $100 \mathrm{~mm}$ Tris- $\mathrm{HCl}(\mathrm{pH} \mathrm{7.4)}$, the specimens were dehydrated with graded steps of ethanol, cleared with xylene, and mounted with Permount (Fisher Scientific Company). Stained specimens were viewed under bright field or phase contrast.

$\beta$-Galactosidase assay. $\beta$-Galactosidase activity was determined according to Simon and Lis (1987) with slight modifications. Twenty heads of each lac $Z$ transformant (2-3 d old) were homogenized on ice with $200 \mu \mathrm{l}$ of buffer containing $50 \mathrm{~mm}$ Tris- $\mathrm{HCl}(\mathrm{pH} 8.0), 0.1 \mathrm{M} \mathrm{NaCl}$, and $0.5 \%$ Triton $\mathrm{X}-100$. The homogenates were centrifuged at $12,000 \mathrm{rpm}$ for $15 \mathrm{~min}$ at $4^{\circ} \mathrm{C}$. An aliquot $(25 \mu \mathrm{l})$ of the supernatant was mixed with $50 \mu \mathrm{l}$ of $10 \mathrm{~mm}$ chlorophenol red- $\beta$-D-galactopyranoside (Boehringer Mannheim) and $450 \mu \mathrm{l}$ of $50 \mathrm{~mm}$ sodium phosphate ( $\mathrm{pH} 7.5$ ) containing $1 \mathrm{mM} \mathrm{MgCl}_{2}$. Reactions were incubated at $37^{\circ} \mathrm{C}$, and the absorbance at $574 \mathrm{~nm}$ was read after a $1 \mathrm{hr}$ incubation. The rate of color development was constant under the condition used in this experiment. $\beta$-Galactosidase activity is expressed in arbitrary units as absorbance/mg protein. Samples were assayed in duplicate.

ChAT assay. Ten female flies ( $1 \mathrm{~d}$ old $)$, heterozygous for the introduced ChAT cDNA fusion constructs and homozygous for the Chats background, were homogenized with $500 \mu$ l of buffer containing $50 \mathrm{~mm}$ 
Figure 1. Putative cis-regulatory region of the Drosophila ChAT gene. The top of the figure shows the genomic organization of the Drosophila ChAT gene (Sugihara et al., 1991). The gene spans more than $26 \mathrm{~kb}$ of DNA and is organized into eight exons, which are indicated by solid boxes. The middle of the figure shows a restriction map of the $7.4 \mathrm{~kb} 5^{\prime}$ flanking region of the ChAT gene. The transcription start site is located at $391 \mathrm{bp}$ upstream from the $\mathbf{3}^{\prime}$ end of the $7.4 \mathrm{~kb}$ fragment and is shown by an arrow. The unusual GTG initiation codon for ChAT protein is located $13 \mathrm{bp}$ downstream from the $3^{\prime}$ end of the fragment and is indicated by an asterisk. The bottom of the figure shows the restriction fragments tested for their cis-regulatory activity in this study, The drawing indicates different amounts of $5^{\prime}$ flanking sequence with the same $3^{\prime}$ portion containing the transcription start site and $391 \mathrm{bp}$ of the first exon shown by shaded boxes.

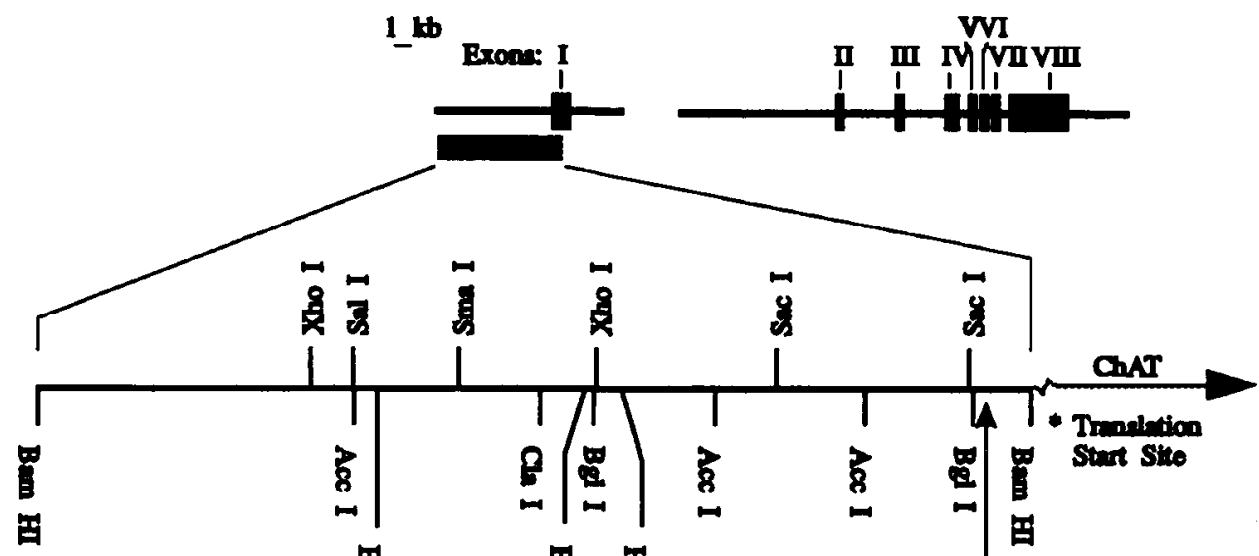

Trenecription Stourt Sifo

Table 1. Summary of $\mathrm{X}$-gal staining

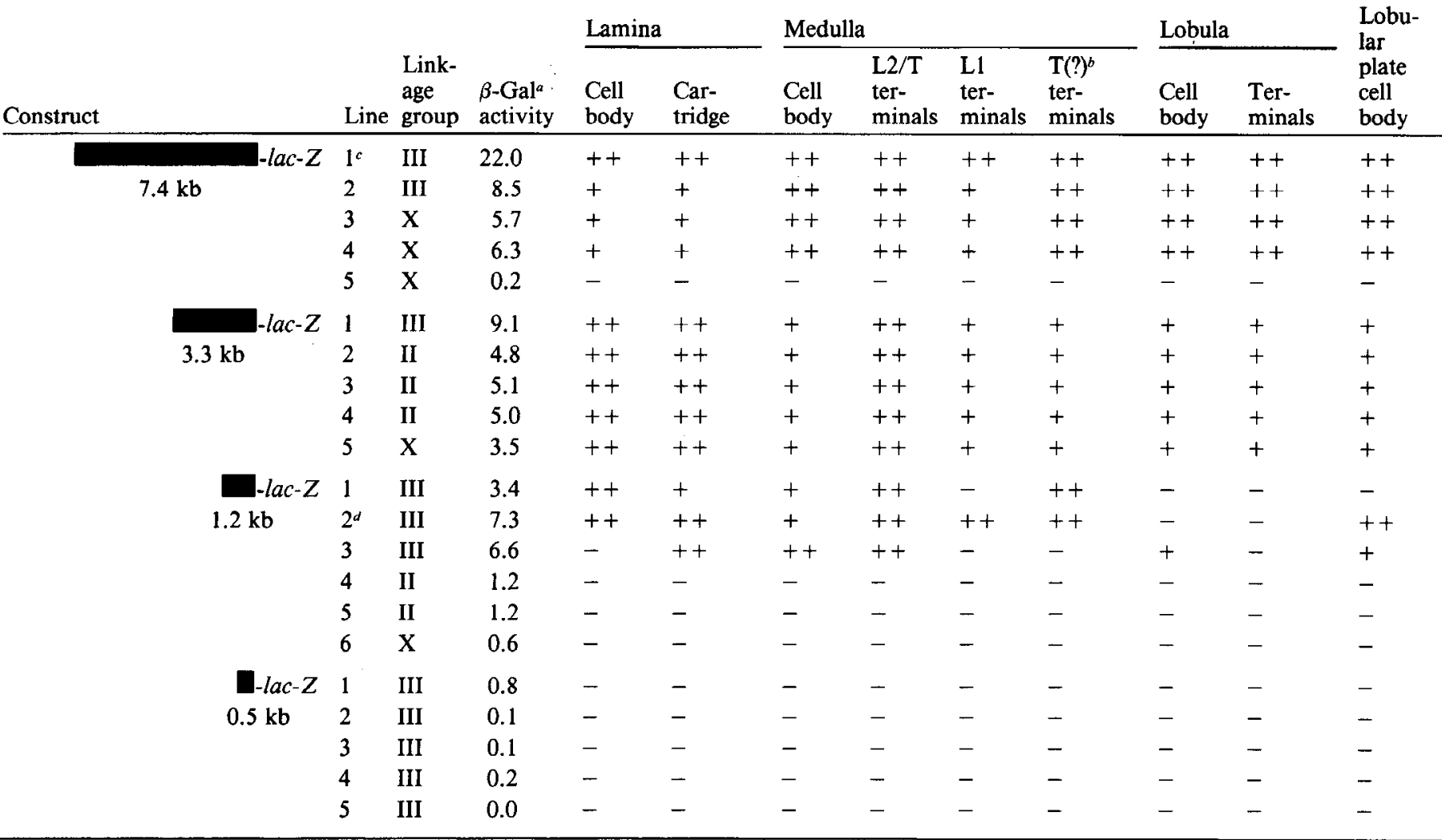

Two $(++)$ signs indicate intense staining, one $(+)$ sign indicates intermediate staining, a $(-)$ sign indicates no staining.

"Activity measured in fly head extracts (see Materials and Methods).

${ }^{b}$ Unidentified terminals, probably from $T$ cells.

c All expression patterns are summarized after incubating sections in X-gal staining solution for 18-24 hr except this line, which was incubated for only $6 \mathrm{hr}$.

$₫$ This line has two P-elements on the third chromosome as determined by Southern blot hybridization and linkage analysis. 
Tris- $\mathrm{HCl}, 0.1 \mathrm{M} \mathrm{NaCl}$, and $0.5 \%$ Triton X-100 (pH 7.5) on ice. Homogenates were frozen and thawed once to solubilize ChAT activity. ChAT activity was assayed by a modification of the procedure of Fonnum (1975) using ${ }^{14} \mathrm{C}$-acetyl-CoA and is expressed as arbitrary radioactivity units/fly. Before measuring the activity, each sample was incubated at $37^{\circ} \mathrm{C}$ for $30 \mathrm{~min}$ to inactivate the endogenous temperature sensitive enzyme activity (Greenspan, 1980; Salvaterra and McCaman, 1985).

Rescue of paralysis. Heterozygous transformants $C h a^{\text {tsl }} / C h a^{\text {isl }}$ and Chass + (10 males and 10 females, 3-4 d old) were placed in standard culture vials in a humidified $30^{\circ} \mathrm{C}$ incubator. Flies were scored for the number still standing up (i.e., not paralyzed) after various incubation times at the clevated tempcrature.

\section{Results}

Figure 1 shows the organization of the Drosophila ChAT gene along with a restriction map of the $7.4 \mathrm{~kb}$ genomic fragment corresponding to the $5^{\prime}$ flanking region we have been studying (Sugihara et al., 1991). The transcription start site of the ChAT gene, determined by primer extension (Sugihara et al., 1990), is located 391 bp upstream of the BamHI site indicated in the $3^{\prime}$ end of this fragment. The unusual (GTG) initiation codon for Drosophila ChAT protein translation (Sugihara et al., 1990) is positioned 13 bp downstream from this same BamHI site and is also indicated on the figure. Figure 1 also shows a schematic representation of the four $5^{\prime}$ flanking genomic fragments tested for cis-regulatory activity in this study. They differ in the amount of 5 ' flanking sequence $(7.4,3.3,1.2$, or $0.5 \mathrm{~kb}$, respectively), and all contain the same 3 ' end including the transcription start site and $391 \mathrm{bp}$ of the untranslated region of the first ChAT exon.

To analyze the $c i s$-regulatory activity of these fragments, they were fused to the bacterial reporter gene $l a c Z$ (encoding $\beta$-galactosidase) and introduced into the Drosophila genome by P-element-mediated germ line transformation. The present study focuses on the expression pattern of lac $Z$ in the optic lobe of adult transformants. The optic lobe is the most obvious ordered structure in the Drosophila cephalic ganglion, making it possible to identify specific synaptic layers in the neuropile and in some cases infer the cells of origin (see Fischbach and Dittrich, 1989). In addition, we have already established the distribution of endogenous ChAT protein in the optic lobe using an anti-ChAT antibody (Ikeda and Salvaterra, 1989) and can thus compare in detail the lac $Z$ expression patterns of transformants with the known distribution of ChAT protein. While the optic lobe of Drosophila is a highly ordered structure, it is not simple. Figure 2 presents a line drawing of the major neuropil regions of the adult optic lobe to simplify discussion of the relevant structures. Also indicated on the figure are a few selected neuronal somata and the trajectories of their major projections that are important for interpreting the $\mathrm{X}$-gal staining patterns.

We have established $5,5,6$, and 5 independent transformant lines for the 7.4, 3.3, 1.2 and $0.5 \mathrm{~kb}-\mathrm{lac} Z$ constructs, respectively. Table 1 presents a bricf summary of the linkage group, quantitative amount of $\beta$-galactosidase expression in adult head extracts of individual lines, and a summary of the spatial distribution patterns of X-gal staining in adult optic lobe for each individual transformant line included in this study.

Although there is some minor variation in the pattern of staining among the various lines, it is possible to make general conclusions regarding the regulatory activity of each tested construct. The pattern of $\beta$-galactosidase expression is determined primarily by the extent of the specific putative regulatory DNA

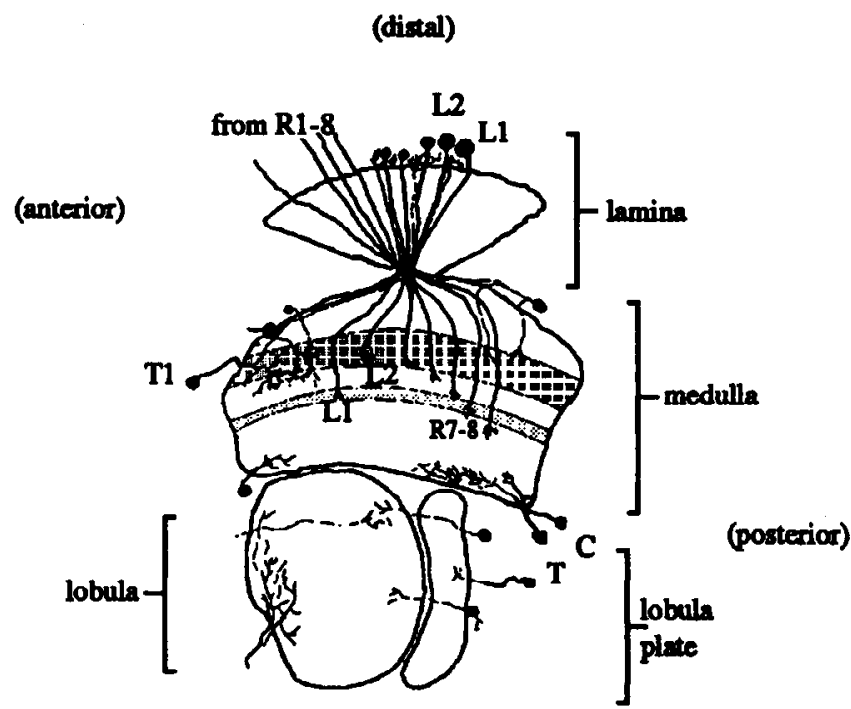

(proximal)

Figure 2. A schematic drawing of the optic lobe of Drosophila melanogaster based primarily on the studies of Fischbach and Dittrich (1989). The optic lobe is subdivided into four neuropil regions shown on the figure: the lamina, medulla, lobula, and lobula plate. The neuropil regions are surrounded by cell body regions, and a few selected cell somata are indicated in the drawing to show thcir major projection patterns into the neuropil. Golgi studies of the neurons in the optic lobe reveal a number of neuronal cell types. They can be classified as either columnar or tangential elements with their projections oriented either parallel or perpendicular to the proximal-distal axis of the figure. The lamina monopolar neurons and the medulla $T 1$ neurons are examples of columnar and tangential elements, respectively. $L 1$ and $L 2$ have their cell bodies in the cell body rind just below the retinula cell layer. The axons reach the medulla via the first optic chiasma and penetrate deeply into the medulla, forming relatively large terminals (shaded layers). The cell bodies of tangential $T 1$ neurons are located in the outer layer of the distal cell body rind of the medulla. The fibers of $T 1$ neurons branch at the medullar neuropil surface to form an arborization in the distal medulla (overlapping with the $L 2$ terminal layer) and the proximal laminar cell somal region. The retinula cells $(R 1-8)$ and the laminar monopolar neurons $(L)$ form synapses in distinct layers of the medullar neuropil.

driving expression. The staining pattern observed for the four positively expressing $7.4 \mathrm{~kb}$ lac $Z$ lines was qualitatively similar. All five $3.3 \mathrm{~kb}$ lac $Z$ lines also showed essentially the same pattern relative to each other, but the pattern was different from that observed for the $7.4 \mathrm{~kb}$ transformants (see below). The 1.2 $\mathrm{kb}$ lines showed more variability, but still had an essential "cholinergic" pattern. No X-gal staining was observed for any of the $0.5 \mathrm{~kb}$ transformants, although one line (number 1) had biochemically significant levels of $\beta$-galactosidase activity. This one line may have "trappcd" an unrelated enhancer that directs a low level of expression (i.e., Bellen et al., 1989; Bier et al., 1989).

Our results indicate that the P-element insertion position may also have a significant effect on expression. This is not surprising because a variety of reporter gene expression patterns are observed in enhancer-trap lines with different insertion sites (Bellen et al., 1989; Bier et al., 1989). Quantitative differences were observed in X-gal staining (see below) and $\beta$-galactosidase activity (Table 1) both among different lines for the same construct and among the different constructs. One of the $7.4 \mathrm{~kb}$ lines (line 

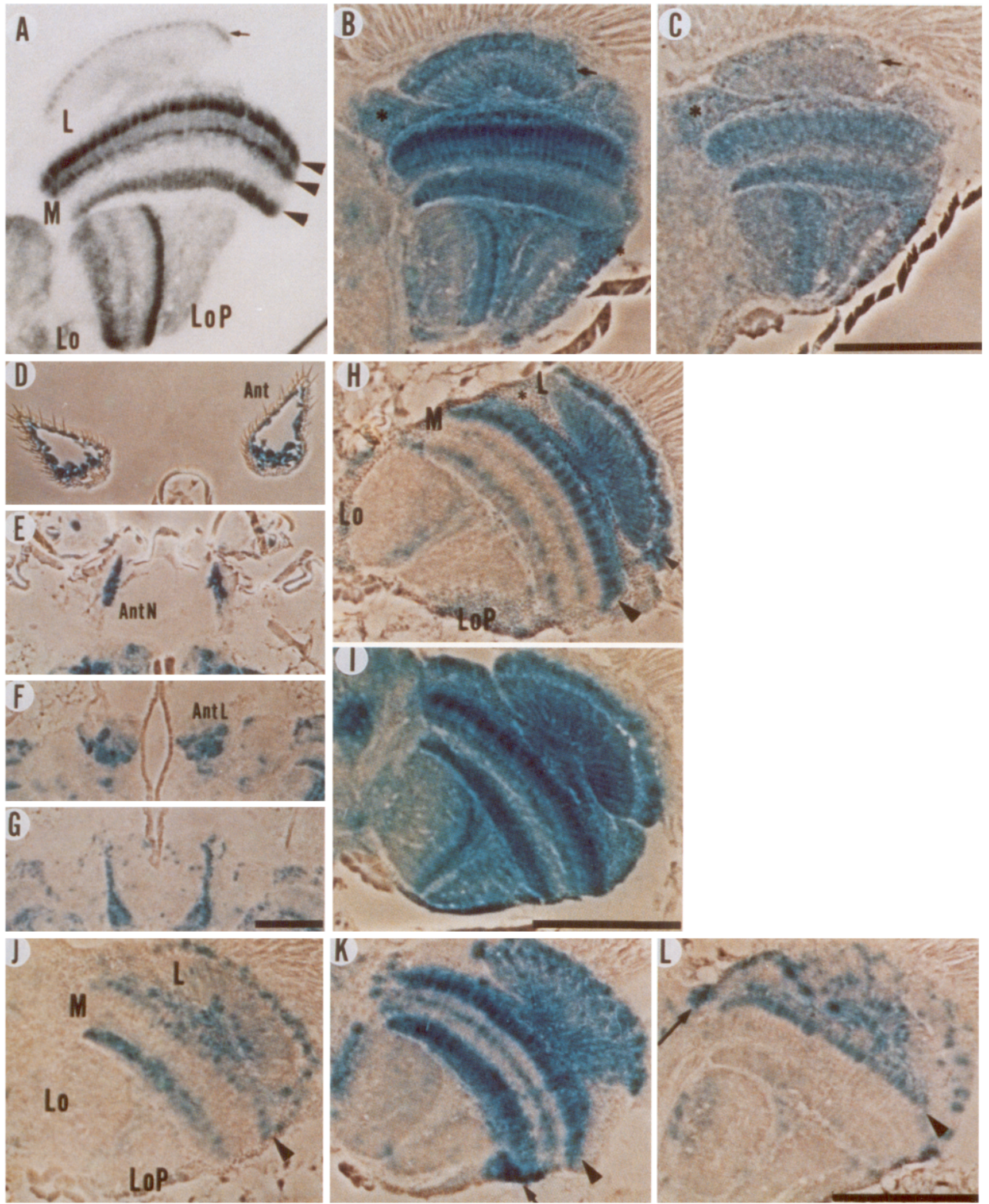

Figure 3. Histochemical analysis of lac $Z$ transformant lines. A, The distribution of endogenous ChAT protein in the optic lobe. A horizontal section of the optic lobe of CantonS was immunochemically labeled with ChAT antibody (Ikeda and Salvaterra, 1989). In the lamina, the radially arranged structure (arrow), and cartridges are moderately stained. In the medulla, three layers can be seen distinctly (arrowheads). Three layers are also stained in the lobula neuropil region. $B$ and $C$, The X-gal staining pattern of $7.4 \mathrm{~kb}$-lac $Z$ transformant line 1 . Cryostat sections of head tissues were prepared and stained in X-gal staining buffer at $37^{\circ} \mathrm{C}$ for $6 \mathrm{hr}(B)$ or $3 \mathrm{hr}(C)$, respectively (see Materials and Methods for details). After $6 \mathrm{hr}$ incubation, most of the ChAT-positive neuropil regions and corresponding cell body regions (marked with asterisks) are stained. Note that the laminar cartridge is not stained after the short incubation time $(C)$ but the radially arranged structure can be observed (arrow in $C$ ). $D-G$, Cryostat 
5) showed no significant $\beta$-galactosidase activity or X-gal staining, possibly indicating insertion into a nonfunctional chromosome position. Of the four positively reporting $7.4 \mathrm{~kb}$ lines, line 1 is quantitatively stronger than the others. Only minor quantitative differences were observed among the five individual $3.3 \mathrm{~kb}$ lines. We have also seen significantly different staining patterns and $\beta$-galactosidase activity when analyzing individual transformant lines derived from the $1.2 \mathrm{~kb}$ construct. No X-gal staining was observed for three of the $1.2 \mathrm{~kb}$ transformants (lines 4-6). Even though we could not detect X-gal staining in some of the $1.2 \mathrm{~kb}$ lines, it was possible to measure significant $\beta$-galactosidase activity by a biochemical assay in all of these lines (sce Table 1).

We have examined several individual specimens for each transformant line under a variety of different staining conditions, and they all show a very consistent reporting pattern. It is unlikely, therefore, that technical differences in our histochemical staining are a factor in the different patterns of X-gal staining we have observed. It is also apparent from the data in Table 1 that we have been able to obtain transformants on all three major chromosomes of Drosophila. We will describe a "typical" pattern for the 7.4 and $3.3 \mathrm{~kb}$ constructs. We also describe the $1.2 \mathrm{~kb}$ pattern in each of the three positive X-gal staining lines.

\section{$\beta$-Galactosidase expression in the optic lobe and other distinct structures of the cephalic ganglion directed by the $7.4 \mathrm{~kb} 5^{\prime}$ flanking sequence}

Figurc $3, A$ and $B$, shows the ChAT protein distribution and the typical X-gal staining pattern seen in the optic lobe of the positively reporting $7.4 \mathrm{~kb}$ lac $Z$ transformant lines. The spatial distribution of X-gal staining showed a pattern very similar to ChAT immunocytochemical staining, as seen by comparing Figure 3, $A$ and $B$. The major difference between ChAT staining and $\mathrm{X}$-gal histochemistry was that X-gal staining, in contrast to ChAT immunocytochemistry, could be observed in some cell somata (asterisks). In the lamina, an arch-shaped structure is stained with both ChAT antibody and X-gal (arrows). In addition, $X$-gal staining can also be observed in the cell body layer proximal to the basement membrane under the retinula cell layer (Fig. 3B). Based on the location and the relatively large size of the X-gal-stained components, part of this staining is likely to correspond to one or more of the laminar monopolar L-neurons and part is likely to be contributed by nerve endings that project into this region, possibly from medullar $\mathrm{T}$ cells (Fischbach and Dittrich, 1989). The arch-shaped structure is especially apparent in the ChAT stain and is better defined after shorter incubation times in X-gal (compare Fig. 3B,C). The laminar cartridge was also stained with both ChAT antibody and $\mathrm{X}$-gal (Fig. $3 A, B$ ), but only after the longer incubation times in X-gal (compare Fig. 3B,C). Cartridge staining is consistent with the presence of reporter gene expression in the $\mathrm{L}$ cells since the cartridge is made up partly of $L$ cells processes.

In the medulla, some somata in both the proximal and the distal somal regions were stained with $\mathrm{X}$-gal even after short incubation times (Fig. 3C), and these structures probably correspond to the cell bodies of the medullar $T$ neurons or medullar intrinsic neurons. In the neuropil of the medulla, at least three distinctly stained layers appeared along with a more diffuse background staining (Fig. 3B,C). The outermost staining was located at the position of the synaptic layer of laminar neuron 2 (L2) and that of the more diffuse projections of the medullar T neurons. The middle layer, which appeared as a patched structure, may correspond to the synaptic terminal field of laminar neuron 1 (L1) based on its position. The innermost layer corresponds to an area where terminals of the medullar $T$ neurons and other neurons are located. All three layers in the medulla are stained with anti-ChAT antibody (arrowheads in Fig. $3 A$ ). Notice that the sharpness of the staining pattern increases as sections are incubated for longer times in X-gal even as the background staining pattern becomes more diffuse. This may be due to the more discrete localization of the $\mathrm{L} 1$ and $\mathrm{L} 2$ nerve endings relative to the more diffuse distribution of $\mathrm{T}$ cell endings.

In the neuropil of the lobula, several distinct neuropil layers are stained, but the identity of the neurons could not be determined since these regions receive terminals from various neurons. In general, the patterns of X-gal and ChAT staining are comparable. In the somal layer of the lobula, a group of somata in the anteriolateral area was stained. In the lobula plate, some somata in the posteriolateral area were strongly stained (Fig. $3 B, C)$.

The $\beta$-galactosidase expression pattern in the synaptic layers of the optic lobe directed by the $7.4 \mathrm{~kb}$ genomic DNA was thus very similar to the distribution of the endogenous ChAT protein, although ChAT protein was observed only in the neuropil regions. Our results strongly suggest that the $7.4 \mathrm{~kb}$ fragment contains most if not all of the necessary information responsible for determining the correct spatial expression pattern of $\mathrm{ChAT}$ in the adult optic lobe and other parts of the cephalic ganglion (see below).

In the $7.4 \mathrm{~kb}-\mathrm{lac} Z$ transformants, many structures other than the optic lobe also show expression of $\beta$-galactosidase. Although some studies have been done (Buchner et al., 1986; Gorczyca and Hall, 1987), the endogenous ChAT distribution in the adult cephalic ganglion has not been established in detail, making it difficult to precisely compare X-gal staining patterns with normal ChAT distribution. In general, however, we see a good

\footnotetext{
sections of heads from $7.4 \mathrm{~kb}$-lacZ transformant line 3 were stained for $18 \mathrm{hr}$. Cell bodies of primary sensory neurons in the antenna $(D)$ and the corresponding antennal nerves $(E)$ are strongly stained. The glomerulus-like structures in the antennal lobe $(F)$ and fiber tracts projecting to the central body $(G)$ are also stained. $H$ and $I$, The X-gal staining pattern in the optic lobe of $3.3 \mathrm{~kb}-l a c Z$ transformants. $H$, A cryostat section of 3.3 $\mathrm{kb}$-lacZ transformant line 1 stained in X-gal solution for $12 \mathrm{hr}$. The L2 neuron cell body layer (small arrowhead) and the corresponding terminals (large arrowhead) are distinctly stained. I, A cryostat section of the transformant line having six copies of the $3.3 \mathrm{~kb}-$ lac $Z$ construct stained with $\mathrm{X}$-gal for $6 \mathrm{hr}$. In addition to $\mathrm{L} 2$ cell bodies and terminals, parts of the medulla cell body region (marked with asterisks), the proximal medulla and the lobula neuropil regions are clearly stained in $(I)$, whereas the staining of these regions in homozygous $3.3 \mathrm{~kb}-l a c Z$ transformant $(H)$ are not obvious. $J-L$, The X-gal staining pattern in the optic lobe of $1.2 \mathrm{~kb}$-lac $Z$ transformants. Only three out of six $1.2 \mathrm{~kb}$-lac $Z$ transformant lines showed significant staining in the optic lobe: $J, 1.2 \mathrm{~kb}-\mathrm{lacZ}$ line $1 ; K, 1.2 \mathrm{~kb}$-lacZ line $2 ; L, 1.2 \mathrm{~kb}$-lacZ line 3 . All were incubated in X-gal solution for $22 \mathrm{hr}$ at $37^{\circ} \mathrm{C}$. The staining of the $\mathrm{L} 2$ terminal layer is marked with an arrowhead. In line 2, a group of cells in the posteriolateral region in the lobula plate is stained strongly (an arrow in $K$ ). In line 3, the possible staining of the T1 cell body layer is marked with an arrow. $L$, lamina; $M$, medulla; $L o$, lobula; $L o P$, lobula plate; $A n t$, antenna; $A n t N$, antennal nerve; $A n t L$, antennal lobe. Scale bars $(A-C, D-G, H$ and $I$, and $J-L)$, $50 \mu \mathrm{m}$.
} 
correlation between positive reporter gene staining in regions that are defined. For example, the antennal sensory neurons are known to contain a significant amount of ChAT message (Barber et al., 1989). As shown in Figure $3 D$, prominent X-gal staining was also observed in the cell bodies of the primary sensory neurons in the antenna. This pattern is in contrast to the visual system, where primary photoreceptor cells were never prominently stained. Staining was also observed along the antennal nerve and within the antennal lobe (Fig. $3 E, F$ ), where strong ChAT immunoreactivity has been reported (Buchner et al., 1986; Gurczyca and Hall, 1987; Ikeda and Salvaterra, 1989). The prominent fiber bundle connecting the aritennal lobe with the calyx and the dorsolateral protocerebrum (antennal glomerular tract) was also stained well by X-gal (Fig. $3 G$ ), again in agreement with the immunocytochemical studies. Staining could also be observed in various other neuropil regions and cell body regions widely distributed throughout the central brain complex.

\section{$\beta$-Galactosidase expression resulting from deletions of the 7.4 $k h$.' flanking DNA}

In order to define more precisely the properties and molecular limits of the cis-regulatory elements within the $7.4 \mathrm{~kb}$ fragment, we constructed a series of $5^{\prime}$ deletions (see Fig. 1) and examined several transformant lines for their resulting $\beta$-galactosidase expression patterns. Deletion of the distal $4.1 \mathrm{~kb}$ of DNA resulted in transformants with an X-gal staining pattern different from the $7.4 \mathrm{~kb}$ pattern. The most obvious difference between the 7.4 and $3.3 \mathrm{~kb}$ expression patterns was the less extensive staining pattern observed for all the $3.3 \mathrm{~kb}$ lines. Staining of the middle and innermost neuropil layer of the medulla and the neuropil region of the lobula/lobula plate was greatly reduced or absent (Fig. $3 H$ ). In addition, the $3.3 \mathrm{~kb}$ lines showed an enhanced staining of L cell soma (probably L2, small arrowhead in Fig. $3 H$ ), laminar cartridge processes, and their corresponding projections within the medulla neuropil at the level of the L2 synapses (large arrowhead in Fig. $3 H$ ). The morc diffusc staining within the distal medulla neuropil observed in $7.4 \mathrm{~kb}$ lines is significantly reduced in the $3.3 \mathrm{~kb}$ lines. This can be explained by the loss of extensive $T$ cell reporting, as well as the $T$ cell projections into both of these regions. It thus seems likely that part of the cis-DNA in the distal $4.1 \mathrm{~kb}$ of the original $7.4 \mathrm{~kb}$ $5^{\prime}$ fragment contains elements that alone, or in combination with the remaining $3.3 \mathrm{~kb}$ elements, act to generate a more broadly distributed pattern of reporter gene expression.

The $3.3 \mathrm{~kb}$ pattern can thus be described as a subset of the elements reporting in the $7.4 \mathrm{~kb}$ lines. We do not believe that the less extensive staining pattern of the $3.3 \mathrm{~kb}$ lines is a result of only quantitative differences in overall expression since the $7.4 \mathrm{~kb}$ lines did not show such a staining pattern even after short incubation in X-gal (see Fig. 3C).

Although the intensity was low, neuropil staining, other than the outermost medulla layer, could also bc observed in the 3.3 $\mathrm{kb}-\mathrm{lac} Z$ transformants. For example, weak sporadic staining could be seen in the middle and proximal medullar neuropil layers (Fig. $3 H$ ) as well as the lobula/lobula plate. To analyze further the relative contribution of qualitative versus quantitative regulatory elements in generating the $3.3 \mathrm{~kb}$ pattern, we constructed a line containing six rather than the normal two copies of the $3.3 \mathrm{~kb} \mathrm{5}$ flanking DNA. For this purpose, three independent $3.3 \mathrm{~kb}$ lines (lines 1,2 , and 5 ) were crossed and their $\beta$-galactosidase expression pattern determined. The resultant transformants showed an increase in reporter gene expres- sion levels in all the regions seen for lines containing only two copies of the $3.3 \mathrm{~kb}$ cis-DNA. The staining in the middle and innermost layer of the medulla neuropil as well as the neuropil separating the lobula and lobula platc could be clearly seen in the multiple copy lines (Fig. 3I). While this staining pattern looks more widely distributed than that of individuals with only two copies of the construct, the pattern is not that of the 7.4 $\mathrm{kb}$-lacZ transformants (Fig. $3 B$ ). For example, the somata in the posteriolateral region of the lobula plate were not stained well, even after a relatively long incubation in X-gal. This region was one of the most intensely stained in $7.4 \mathrm{~kb}$-lac $Z$ transformants (Fig. $3 B$ ). In addition, the $\mathrm{L}$ neuron somal layer in the lamina showed more distinct staining in the multiple copy 3.3 $\mathrm{kb}-\mathrm{lac} Z$ transformants when compared with $7.4 \mathrm{~kb}$-lacZ transformants. Also, the staining of the outer neuropil layer of the medulla was sharper in appearance, suggesting that the contribution of the $\mathrm{L} 2$ neurons to the staining in $3.3 \mathrm{~kb}-l a c Z$ lines is much more prominent than that of the medullar $T$ neurons. In addition, even in multiple-copy $3.3 \mathrm{~kb}$-lac $Z$ transformants, the innermost medullar neuropil staining was distributed less extensively than the $7.4 \mathrm{~kb}$ lines. We thus conclude that a major function of elements in the distal $4.1 \mathrm{~kb}$ of cis-DNA is to contribute qualitatively to the distribution of cholinergic cells in adult optic lobe.

We also analyzed transformants carrying either $1.2 \mathrm{~kb}$ or 0.5 $\mathrm{kb}$ of proximal genomic DNA. No X-gal staining was observed in the optic lobe of five independent lines containing only 0.5 $\mathrm{kb}$ of putative $c i s$-DNA. This indicates that the most proximal part of the ChAT gene lacks essential elements required for normal expression. Interestingly, however, one of the $0.5 \mathrm{~kb}$ lines (line 1) had biochemically significant levels of $\beta$-galactosidase activity (see Table 1).

Patterns of X-gal staining in the lines containing $1.2 \mathrm{~kb}$ of 5 flanking DNA are more complex. Three (lines 1-3) of the six independent lines examined showed significant staining in the optic lobes, while the other three (lines 4-6) showed little if any staining in this region of the nervous system. Among the lines showing significant staining, there was a difference in the distribution of staining, although the pattern was consistent for each line when different individuals of the same line were analyzed. All six $1.2 \mathrm{~kb}$ transformant lines showed biochemically significant levels of $\beta$-galactosidase activity, although the levels in the three negatively staining lines were low (Table 1).

Figure $3 J-L$ shows the characteristic patterns for each of the three positively reporting $1.2 \mathrm{~kb}$ transformant lines. In the 1.2 $\mathrm{kb}-\mathrm{lac} Z-1$ line, the somal layer under the retinula cell layer, probably corresponding to the cell body layer of the $\mathrm{L}$ neurons, is sporadically stained. The number of stained cell bodies seems to be less than that seen in either the 3.3 or $7.4 \mathrm{~kb}$ transformants. A few cells are stained in the cell body region of the medulla. In the medulla neuropil, the layer corresponding to the L2 terminals was also staincd sporadically (arrowhead, Fig. $3 J$ ). The sporadic staining pattern is thus seen in both the cell soma and its projection field, possibly indicating a direct relationship between the two. The innermost layer of the medulla and the lobula neuropil are also stained faintly and sporadically.

As shown in Figure $3 K$, the $1.2 \mathrm{~kb}-\mathrm{lac} Z-2$ line showed a similar X-gal staining pattern as the $1.2 \mathrm{~kb}-\mathrm{lacZ}-1$ line, but the staining was more intense. The lamina cartridge is stained in this line, but unlike the 7.4 or $3.3 \mathrm{~kb}$ lines, the staining appears as dots rather than being evenly distributed throughout the cartridge. In the medulla neuropil, not only the outermost layer 
(arrowhead, Fig. $3 K$ ) but also the middle and innermost layers were stained. Unlike the $1.2 \mathrm{~kb}-l a c \angle-1$ line, this line showed strong expression of $\beta$-galactosidase in some cell bodies in the posteriolateral area of the lobula plate (arrow, Fig. $3 K$ ). This same group of cells was stained very well in $7.4 \mathrm{~kb}$-lacZ transformants (see Fig. $3 B$ ) but not in $3.3 \mathrm{~kb}$-lac $Z$ transformants (see Fig. $3 H)$.

In the $1.2 \mathrm{~kb}-$ lac $Z-3$ line, the staining was even more restricted than the $1.2 \mathrm{~kb}-\mathrm{lacZ}-1$ line (Fig. $3 L$ ). Staining in the somal layer of the lamina was not observed. One interesting feature of this line is that the laminar cell body region appears to be deformed. It is possible that the P-element insert in this line has disrupted laminar development by inactivating some unknown genetic function. In the lamina cartridge, we see scattered staining. In the medulla, the outermost layer was stained weakly and sporadically. X-gal staining was also observed in the somal regions of medulla but appeared to be concentrated in the lateral regions (arrow, Fig. 3L). This staining pattern resembles a T1-cell-specific staining pattern observed with an HHA09 antiserum raised to hydra hcad immunogen (Bucher et al., 1988).

Although the three positive $1.2 \mathrm{~kb}$ transformant lines were all different in their detailed staining patterns, it is relevant to point out that the staining is still confined to subsets of neurons, processes, and terminals that were also positive in the 7.4 and/ or $3.3 \mathrm{~kb}$ lines. The $1.2 \mathrm{~kb} \mathrm{5'} \mathrm{flanking} \mathrm{DNA} \mathrm{must} \mathrm{therefore}$ contain a significant amount of "cholinergic" neuron-specific regulatory activity. The $1.2 \mathrm{~kb}$ of $5^{\prime} \mathrm{DNA}$ may not be strong enough, however, to direct adequate levels of $\beta$-galactosidase activity necessary for detection by $\mathrm{X}$-gal staining. Expression of this construct may also be influenced by more generally acting enhancer elements (i.e., unrelated to cholinergic expression patterns per se) that are in close proximity to the random insertion position of the P-element constructs.

\section{Rescue of mutants using 5'flanking DNA fused to wild-type ChAT cDNA}

The histochemical studies of $\beta$-galactosidase reporter gene expression in the lac $Z$ transformants suggested the existence of both qualitative and quantitative regulatory elements in the $5^{\prime}$ flanking $7.4 \mathrm{~kb}$ region of the ChAT gene. To examine the functional significance of these elements, we constructed several transformant lines where the 5 ' flanking DNA was used to drive expression of wild-type Drosophila ChAT cDNA, rather than the nonfunctional $l a c Z$ reporter gene. These lines were prepared by transforming Drosophila stocks with a genetic background homozygous for a temperature-sensitive allele ( $\left.C h a^{s s}\right)$ of ChAT (Greenspan, 1980). Mutant enzyme is rapidly inactivated at high temperatures, while enzyme derived from the recombinant clone is relatively stable (Tajima and Salvaterra, 1990). It is thus possible to distinguish the contribution of wild-type enzyme (provided by the P-element transformation and directed by appropriate regulatory sequence) from the endogenous mutant ChAT by incubating extracts at nonpermissive temperature before enzyme assay. In addition, we can also determine if these constructs can rescue any of the $C h a^{\text {st }}$ mutant phenotypes (Greenspan, 1980) by challenging transformants with high temperature.

We obtained several independent transformant lines for each cDNA construct using $7.4,3.3,1.2$, or $0 \mathrm{~kb}$ of $5^{\prime}$ flanking DNA. All of the constructs, except those containing $0 \mathrm{~kb}$ of genomic DNA (i.e., transformation with only the wild-type ChAT cDNA),
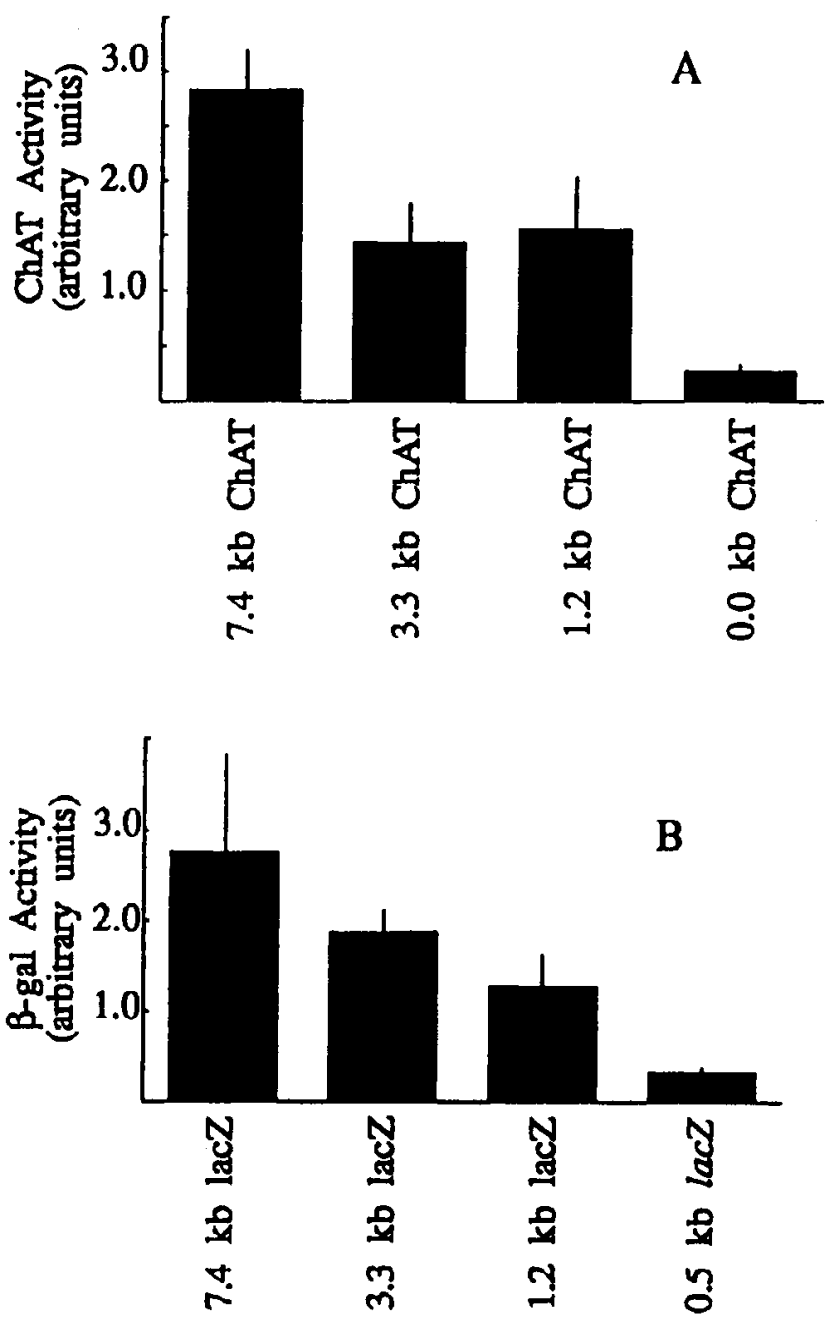

Figure 4. ChAT and $\beta$-galactosidase activity levels in transformants with different length of $5^{\prime}$ flanking DNA. $A$, ChAT activity levels for ChAT cDNA transformant lines were determined after samples were preincubated at $37^{\circ} \mathrm{C}$ for $30 \mathrm{~min}$ to inactivate the endogenous temperature-sensitive enzyme activity. Bars represent the average ChAT activity of different lines transformed with the same construct. The line on each bar represents SEM. Significant differences at the $5 \%$ level were calculated for $7.4 \mathrm{~kb}$ versus all others as well as for $0.0 \mathrm{~kb}$ versus all others using the Wilcoxon test. $B, \beta$-Galactosidase activity levels in the heads of lac $Z$ transformant lines. Bars represent the average activity of different transformant lines with the same construct. The line on each bar represents SEM. Significant differences at the 5\% level were calculated for the $7.4 \mathrm{~kb}$ constructs versus others as well as the $0.5 \mathrm{~kb}$ constructs versus others. See Materials and Methods for additional details.

were able to direct expression of significant levels of wild-type recombinant $\mathrm{ChAT}$ in transformants as shown in Table 2 and summarized in Figure $4 \mathrm{~A}$. Samples were preincubated at $37^{\circ} \mathrm{C}$ for 30 min before assaying enzyme activity, a condition that effectively reduces mutant enzyme activity to less than a few percent while having only a minimal effect on wild-type enzyme. The relative order of the wild-type ChAT activity directed by each construct (i.e., considering individual lines as a group based on the extent of $5^{\prime}$-flanking DNA) was $7.4 \mathrm{~kb}>3.3 \mathrm{~kb} \simeq 1.2$ $\mathrm{kb}>0 \mathrm{~kb}$. Smaller pieces of genomic DNA thus result in less wild-type ChAT expression. This result is in rough agreement with the $\beta$-galactosidase activity of the $L a c Z$ transformants, which are also summarized in Figure $4 B$ for comparison. It is somewhat surprising, however, that we see no significant dif- 


\begin{tabular}{|c|c|c|c|}
\hline Construct & Line & $\begin{array}{l}\text { Linkage } \\
\text { group }\end{array}$ & $\begin{array}{l}\text { ChAT } \\
\text { activitya }\end{array}$ \\
\hline \multirow[t]{10}{*}{$7.4 \mathrm{~kb} \mathrm{ChAT}$} & 1 & III & 2.38 \\
\hline & 2 & III & 2.76 \\
\hline & 3 & III & 4.03 \\
\hline & 4 & II & 4.29 \\
\hline & 5 & III & 4.74 \\
\hline & 6 & $\mathrm{X}$ & 1.74 \\
\hline & 7 & III & 1.63 \\
\hline & 8 & II & 2.66 \\
\hline & 9 & III & 2.72 \\
\hline & 10 & III & 1.39 \\
\hline \multirow[t]{4}{*}{$3.3 \mathrm{~kb}$ ChAT } & 1 & III & 2.04 \\
\hline & 2 & II & 2.11 \\
\hline & 3 & III & 0.77 \\
\hline & 4 & III & 0.78 \\
\hline \multirow[t]{6}{*}{$1.2 \mathrm{~kb}$ ChAT } & 1 & $\mathrm{X}$ & 0.76 \\
\hline & 2 & II & 2.19 \\
\hline & 3 & II & 0.77 \\
\hline & 4 & III & 1.36 \\
\hline & 5 & III & 0.58 \\
\hline & 6 & II & 3.62 \\
\hline \multirow[t]{5}{*}{$0 \mathrm{~kb}$ ChAT } & 1 & ND & 0.46 \\
\hline & 2 & III & 0.16 \\
\hline & 3 & HI & 0.31 \\
\hline & 4 & II & 0.29 \\
\hline & 5 & III & 0.19 \\
\hline
\end{tabular}

ND, not determined.

a Recombinant wild-type ChAT activity measured in fly homogenates after 30 min incubation at $37^{\circ} \mathrm{C}$ to inactivate endogenous Chas' ChAT (see Materials and Methods for further details). ferences between the 3.3 and $1.2 \mathrm{~kb}$ cDNA or $L a c Z$ transformants considering the significant $\beta$-galactosidase staining differences already described. If each line is considered individually for wild-type ChAT expression (Table 2) or $\beta$-galactosidase activity (Table 1), it is apparent that there is considerable overlap in the levels of either enzyme in individual lines of a given construct.

In the cDNA transformants, wild-type recombinant ChAT expression is expected to be controlled by the cis-regulatory activity of the fused genomic sequences. Since we have seen quantitatively and qualitatively different patterns for these putative cis-regulatory sequences directing reporter gene expression, it is interesting to examine the ability of the different $c D N A$ constructs to rescue temperature induced mutant phenotypes.

All of the cDNA transformants containing $5^{\prime}$ flanking sequences were rescued from temperature-induced adult lethality. In fact even one of the $0 \mathrm{~kb}$ transformant lines was rescued (line 1) after incubating flies at $30^{\circ} \mathrm{C}$ for several days. Even the 1.2 $\mathrm{kb}$ of 5' flanking DNA is sufficient to direct enough wild-type ChAT activity to spare the flies from death. We have also examined the different transformants for rescue of adult flies from temperature-induced paralysis (Greenspan, 1980). Transformant lines, homozygous for the $C h a^{t s l}$ allele and heterozygous for the P-element inserts, were incubated at $30^{\circ} \mathrm{C}$ for various times and assayed for the number of flies standing up (i.e., not paralyzed). The data are summarized in Table 3 . All of the flies transformed with cDNA constructs containing 5 ' lanking DNA were rescued relative to the mutant phenotype. Even after $6 \mathrm{~d}$ at $30^{\circ} \mathrm{C}$, all but one of the $1.2 \mathrm{~kb}$ and two of the $7.4 \mathrm{~kb}$ lines were still able to move normally and all lines were still alive. Under this same condition, all $C h a^{t s l}$ flies would be dead. As expected from the ChAT activity measurements, all but one of the $0 \mathrm{~kb}$ cDNA transformant lines were paralyzed after $66 \mathrm{hr}$. Surprisingly, however, one of the $0 \mathrm{~kb}$ cDNA lines was efficiently rescued (see Table 3). It is interesting to note that this line, while containing no $5^{\prime}$ flanking DNA, contains two independent insertions of the P-element vector with wild-type ChAT cDNA.

\begin{tabular}{|c|c|c|c|c|c|}
\hline \multirow{2}{*}{$\begin{array}{l}\text { Construct or } \\
\text { genotype }\end{array}$} & \multicolumn{5}{|c|}{ Incubation time at $30^{\circ} \mathrm{C}(\mathrm{hr})$} \\
\hline & 19 & 56 & 66 & 91 & 143 \\
\hline \multirow[t]{3}{*}{$7.4 \mathrm{~kb}$} & $20(10 / 10)$ & $20(10 / 10)$ & $20(9 / 10)$ & $20(8 / 10)$ & $20(8 / 10)$ \\
\hline & & & $18(1 / 10)$ & $13(1 / 10)$ & $10(1 / 10)$ \\
\hline & & & & $10(1 / 10)$ & $8(1 / 10)$ \\
\hline $3.3 \mathbf{~ k b}$ & $20(4 / 4)$ & $20(4 / 4)$ & $20(4 / 4)$ & $20(4 / 4)$ & $20(4 / 4)$ \\
\hline \multirow[t]{2}{*}{$1.2 \mathrm{~kb}$} & $20(4 / 4)$ & $20(4 / 4)$ & $20(4 / 4)$ & $20(3 / 4)$ & $20(3 / 4)$ \\
\hline & & & & $19(1 / 4)$ & $8(1 / 4)$ \\
\hline \multirow[t]{4}{*}{$0 \mathbf{~ k b}$} & $20(5 / 5)$ & $20(2 / 5)$ & $0(4 / 5)$ & $0(4 / 5)$ & $0(4 / 5)$ \\
\hline & & $9(1 / 5)$ & $20(1 / 5)$ & $20(1 / 5)$ & $20(1 / 5)$ \\
\hline & & $6(1 / 5)$ & & & \\
\hline & & $3(1 / 5)$ & & & \\
\hline CantonS & & & 20 & & 20 \\
\hline$w: C h a^{s s t}$ & & & 0 & & No survivors \\
\hline
\end{tabular}

Twenty flies for each construct and genotype were tested and the number of filies still standing up (i.e., not paralyzed) after the indicated times at $30^{\circ} \mathrm{C}$ is indicated. The data in parentheses show the number of lines for each construct exhibiting the indicated behavior relative to the total number of lines tested. All transformants were homozygous for the $C h a^{i s i}$ allele. 


\section{Discussion}

Using a $7.4 \mathrm{~kb}$ genomic fragment corresponding to the $5^{\prime}$ flanking region of the ChAT gene, P-element-transformed flies express $\beta$-galactosidase reporter gene activity in a pattern essentially identical to the distribution of ChAT protein in adult cephalic ganglion. In addition, we have rescued flies homozygous for a temperature-sensitive allele of ChAT by transforming them with the same $5^{\prime}$ genomic sequences directing expression of wild-type ChAT cDNA. These results strongly suggest that the $7.4 \mathrm{~kb}$ of $5^{\prime}$ flanking DNA contains all the necessary genomic regulatory information responsible for correct spatial expression pattern of the ChAT gene in the adult cephalic ganglion. It is thus not necessary to propose the existence of any other essential elements in the introns, 3 ' flanking sequences, or ChAT protein coding sequences to obtain the correct spatial expression pattern. Our results do not completely rule out the presence of other regulatory elements not represented in the $7.4 \mathrm{~kb}$ of $5^{\prime}$ flanking DNA since we have not completely analyzed the expression pattern as a function of developmental stage or in other parts of the nervous system known to contain cholinergic neurons, such as the thoracic ganglion and the peripheral sensory neurons. Our general impression, however, is that the $7.4 \mathrm{~kb} 5^{\prime}$ flanking region is also sufficient to reproduce the normal ChAT expression pattern in these other structures. In the present study, we have focused on the lac $\angle$ expression pattern in the adult cephalic ganglion, with special interest in the optic lobe since this region is the best characterized with respect to normal ChAT distribution.

One of the major differences in the $\mathrm{X}$-gal staining patterns and the immunocytochemical distribution of ChAT protein is that X-gal staining can be observed in cell soma while ChAT staining is confined to the neurnpil (Ikeda and Salvaterra, 1989). It has thus been possible to conclude that some of the laminar $L$ neurons are cholinergic based on both the $X$-gal staining patterns and the distribution of ChAT immunocytochemical reaction product in the L2 and L1 terminal fields of the medulla. In addition, a large fraction of the medullar $T$ cells are also stained positively with X-gal, and their diffuse projection fields into the laminar somal layer and medullar neuropil are probably contributing to the diffuse pattern of staining seen in $7.4 \mathrm{~kb}$ transformants after short staining times. The proximal most $\mathrm{X}$-gal staining we have observed in the medullar neuropil is also probably coming from $\mathrm{T}$ and/or $\mathrm{C}$ cells of the medulla, lobula, and lobula plate. It is also interesting to note that even though $\mathrm{X}$-gal staining is present in neuronal soma, the staining is also quite intense in the cell processes and in particular in the nerve endings. This result was unexpected since our constructs contain no ChAT protein coding sequences.

In general it is believed that ChAT mRNA is translated in the cell soma and the protein is specifically transported to the nerve endings. The recombinant $\beta$-galactosidase produced in the transformants does not contain any neuronal protein sequence, yet it too is apparently concentrated in nerve endings. One potentially relevant feature of our constructs in this regard is that all the LacZ transformants contain $391 \mathrm{bp}$ of the first exon of the ChAT gene (Sugihara et al., 1991). Even though this sequence is entirely within the 5 ' noncoding region of ChAT, it could be contributing to the expression patterns we have observed. In vitro translation experiments have implicated this region in translational control (Sugihara et al., 1990), but it is also possible that this sequence contributes to the subcellular distribution pattern we have observed. Perhaps subcellular routing information is present in the untranslated 5' ChAT leader sequence, which is part of our constructs. Some other studies have also observed $\beta$-galactosidase reporter gene activity in nerve endings and neuropil regions (see, e.g., Fortini and Rubin, 1990). This localization is usually attributed to filling of the whole neuron with $\mathrm{X}$-gal staining product.

The $5^{\prime}$ deletion analysis of the $7.4 \mathrm{~kb}$ flanking DNA revealed that the ChAT regulatory region is relatively large and complex. One of the most interesting findings is that smaller pieces of the 5 ' flanking DNA retain the ability to direct ChAT expression in various subsets of cholinergic neurons while losing positive expression in other subsets of neurons. Our results indicate that the DNA contains multiple regulatory elements for specifying the cholinergic neurotransmitter phenotype. Deletion of the distal $4.1 \mathrm{~kb}$ of DNA from the $7.4 \mathrm{~kb}-\mathrm{lac} Z$ fusion gene resulted in both quantitative and qualitative effects on $\beta$-galactosidase expression in the optic lobe. We can infer the presence of both positive and negative regulatory elements in the distal regulatory region of the ChAT gene since some staining was reduced and/ or lost (i.e., medullar $\mathrm{T}$ cells and lobula neuropil) while other staining appeared to be increased (i.e., laminar $\mathrm{L} 2$ cell bodies and the laminar cartridge). Our data allow us to propose the existence of cholinergic neuron subset-specific regulatory elements in the distal $4.1 \mathrm{~kb}$ INA.

The $\beta$-galactosidase expression pattern in the $1.2 \mathrm{~kb}-\mathrm{lac} Z$ transformants revealed even more complexity. Part of the reason for the different $1.2 \mathrm{~kb}$ patterns we have observed is likely to be due to technical limitations of X-gal staining. It is apparent from the data in Table 1 that we can easily detect $\beta$-galactosidase activity in all of the $1.2 \mathrm{~kb} \mathrm{LacZ}$ transformants with a biochemical assay, while only three of the $1.2 \mathrm{kh}$ lines showed significant $\mathrm{X}$-gal staining. It is also possible that the $1.2 \mathrm{~kb}$ constructs are susceptible to influence from other non-cholinergic regulatory sequences near the position of the P-element insertion sites. Position effects alone, however, are not likely to account for the more general features of the $1.2 \mathrm{~kb}$ transformant lines. We believe that the $1.2 \mathrm{~kb}$ fragment contains essential cholinergic specific regulatory elements. For instance, we have not observed any ectopic expression of X-gal staining in noncholinergic neurons or other non-neuronal cell types. There are also some common features of the $1.2 \mathrm{~kb}$ staining pattern. For example, the most distal staining of the medullar neuropil was observed in all three positive $1.2 \mathrm{~kb}$ lines. Some of the sensory neurons in antenna were not stained even in optic lobe-positive $1.2 \mathrm{~kb}$ lines, while most, if not all, of them were stained in both $3.3 \mathrm{~kb}$ and $7.4 \mathrm{~kb}$ transformants (data not shown). In addition, all of the $1.2 \mathrm{~kb}$-cDNA constructs were able to rescue the temperature-dependent lethality and paralysis phenotypes of $C h a^{t s t}$ mutants. Our results strongly suggest that the $1.2 \mathrm{~kb}$ fragment can direct the expression of wild-type ChAT in essential cholinergic neurons. These observations are consistent with the hypothesis that the regulatory region of the ChAT gene can be divided into subset-specific elements. It is also important to remember that $\mathbf{P}$-element insertion can itself be a form of mutagenesis. One of the $1.2 \mathrm{~kb}$ transformant lines we have produced shows an abnormal structure in the lamina and is thus probably disrupting a function(s) essential for normal laminar organization.

The functional importance of the $5^{\prime}$ flanking region of the 
ChAT gene is confirmed by the rescue of two temperaturedependent mutant phenotypes by the wild-type cDNA transformants. It is a bit surprising that rescue can be accomplished by the smaller $5^{\prime}$ flanking sequences, in view of their less extensive reporting patterns seen with $\mathrm{X}$-gal staining. Perhaps only certain critical cholinergic cells are necessary for prevention of lethality and paralysis. It will be important to test the functional aspects of the independent regulatory elements using other phenotypes that may be controlled more directly by cholinergic neurons such as specific visual and sensory tasks. These other phenotypes may be more likely to be differentially rescued by different regulatory sequences. It is tempting to speculate that the cholinergic subset-specific genomic sequences represent functional coding of higher brain organizational principles within the genome.

Position effects appear to influence the 7.4 and $3.3 \mathrm{~kb}$ constructs in a primarily quantitative fashion. We see considerable variation in the levels of either $\beta$-galactosidase activity or wildtype ChAT activity among the individual transformant lines within a given group of 5' flanking DNA. At least one of the $7.4 \mathrm{~kb}$ cDNA lines approach the normal wild-type levels of ChAT activity (lines 5). There is also an overlap in the levels of expression among individual lines with different lengths of 5 ' flanking DNA. Considered as a group, however, the $7.4 \mathrm{~kb}-$ containing lines have significantly more $\beta$-galactosidase or wildtype ChAT expression than any of the other transformant lines. It is also rather surprising that the 3.3 and $1.2 \mathrm{~kb}$ lines have about the same amount of $\beta$-galactosidase or wild-type ChAT activity considcring the significant differences in staining intensity and distribution. This result may indicate the relative independence of spatial and quantitative control elements. The relative insensitivity of the $\mathrm{X}$-gal staining assay is also likely to contribute to this apparently contradictory result.

$\mathrm{ACh}$ is a major transmitter in the nervous system of all animals including Drosophila. We have demonstrated that a relatively large and complex regulatory region of the ChAT gene is involved in specifying the numerous cholinergic neurons distributed throughout the nervous system. It is perhaps not surprising that individual subsets of cholinergic cells are apparently specified by separable regulatory elements. The functional demands on different types of cholinergic neurons, such as the primary sensory neurons in the antennal system, must be quite different than neurons involved in integrating visual information, such as the laminar L1 and L2 cells or the medullary T cells. Different types of cholinergic neurons are likely to have evolved complex regulatory sequences to account for some of these diverse functional demands. It is likely that the microenvironment of different cholinergic cells is different depending on their specific location within the brain. The constellation of factors produced by surrounding cells presumably determines the epigenetic signals responsible for determining the set of transcription factors within a given neuron. It is ultimately these transcription factors that interact with the cis-regulatory DNA of the ChAT gene.

It is not likely that the specific regulatory elements we have identified for Drosophila will be used entirely by other species to regulate cholinergic expression, since other species have functionally different cholinergic cells such as vertebrate motor neurons. It is important to note, however, that an increasing number of cis-DNA regulatory motifs are homologous in Drosophila and other animals such as vertebrates. It is also probable that the principle of subset-specific genetic control elements will also be found to specify cholinergic cells in other species. Such a mechanism could perhaps account for the differential susceptibility of subsets of neurons to disease processes such as the loss of the basal forebrain cholinergic neurons in Alzheimer's disease (i.e., McGeer et al., 1944).

\section{References}

Barber RP, Sugihara H, Lee M, Vaughn JE, Salvaterra PM (1989) Localization of Drosophila neurons that contain choline acetyltransferase messenger RNA: an in situ hybridization study. J Comp Neurol 280:533-543.

Beall C, Hirsh J (1987) Neuronal and glial expression of the Drosophila decarboxylase gene. Genes Dev 1:510-520.

Bellen HJ, O'kane CJ, Grossniklaus U, Pearson RK, Gehring WJ (1989) P-element-mediated enhancer detection: a versatile method to study development in Drosophila. Genes Dev 3:1288-1300.

Bier E, Vaessin H, Shepherd S, Lee K, McCall K, Barbel S, Ackerman L, Carretto R, Uemura T, Grell E, Jan LY, Jan YN (1989) Searching for pattern and mutation in the Drosophila genome with a P-lac Z vector. Gene Dev 3:1273-1287.

Bray SJ, Johnson WA, Hirsh J, Heberlein U, Tjian R (1988) A cisacting element and associated binding factor required for CNS expression of the $D$. melanogaster dopa decarboxylase gene. EMBO J 7:177-188.

Bray SJ, Burke B, Brown NH, Hirsh J (1989) Embryonic expression pattern of a family of Drosophila proteins which interact with a CNS regulatory element. Genes Dev 3:1 130-1145.

Bucher E, Bader R, Bucher S, Cox J, Emson PC, Flory E, Heizmann CW, Hemm S, Hofbauer A, Oertel WH (1988) Cell-specific immuno-probes for the brain of normal and mutant Drosophila melanogaster. Cell Tissue Res 253:357-370.

Buchner E, Buchner S, Crawford G, Mason WT, Salvaterra PM, Sattelle DB (1986) Choline acetyltransferase-like immunoreactivity in the brain of Drosophila melanogaster. Cell Tissue Res 246:57-62.

Carbini LA, Munoz-Maines VJ, Salvaterra PM (1990) Developmental expression of choline acetyltransferase mRNA in Drosophila. Neurochem Res 15:1089-1096.

Dewhurst SA, McCaman RE, Kaplan WD (1970) The time course development of acetylcholine esterase and choline acetyltransferase in Drosophila melanogaster. Biochem Genet 4:499-508.

Fischbach KF, Dittrich APM (1989) The optic lobe of Drosophila melanogaster. I. A. Golgi analysis of wild-type structure. Cell Tissue Res 258:441-475.

Fonnum $F$ (1975) A rapid radiochemical method for the determination of choline acetyltransferase. J Neurochem 24:407-409.

Fortini ME, Rubin GM (1990) Analysis of cis-acting requirements of the $R h 3$ and $R h 4$ genes reveals a bipartite organization to rhodopsin promoters in Drosophila melanogaster. Genes Dev 4:444-463.

Gorczyca MG, Hall JC (1984) Identification of a cholinergic synapse in the giant fiber pathway of Drosophila using conditional mutations of acetylcholine synthesis. J Neurogenet 1:289-313.

Gorczyca MG, Hall JC (1987) Immunohistochemical localization of choline acetyltransferase during development in the Chats mutants of Drosophila melanogaster. J Neurosci 7:1361-1369.

Greenspan RJ (1980) Mutations of choline acctyltransferase and associated neural defects in Drosophila melanogaster. J Comp Physiol 137:83-92.

Ikeda K, Salvaterra PM (1989) Immunohistochemical study of a temperature sensitive choline acetyltransferase mutant of Drosophila melanogaster. J Comp Neurol 280:283-290.

Itoh N, Slemmon JR, Hawke DH, Williamson R, Morita E, Itakura K, Roberts E, Shively JE, Crawford GD, Salvaterra PM (1986) Cloning of Drosophila choline acetyltransferase cDNA. Proc Natl Acad Sci USA 83:4081-4085.

Johnson WA, Hirsh J (1990) Drosophila 'POU-protein' binds to a sequence element regulating gene expression in specific dopaminergic neurons. Nature 343:467-470.

Johnson WA, McCormick CA, Bray SJ, Hirsh J (1989) A neuronspecific enhancer of the Drosophila dopa decarboxylase gene. Genes Dev 3:676-686.

Karess RE, Rubin GM (1984) Analysis of P transposable element functions in Drosophila. Cell 38:135-146.

McGeer PL, McGeer EG, Suzuki J, Dolman CE, Nagai T (1984) Aging, 
Alzheimer's disease and the cholinergic system of the basal forebain. Neurology 34:741-745.

Patterson PH (1978) Environmental determination of autonomic neurotransmitter functions. Annu Rev Neurosci 1:1-17.

Rubin GM, Spradling AC (1982) Genetic transformation of Drosoph ila with transposable element vectors. Science 218:348-353.

Salvaterra PM, McCaman RE (1985) Choline acetyltransferase and acetylcholine levels in Drosophila melanogaster: a study using two temperature-sensitive mutants. J Neurosci 5:903-910.

Salvaterra PM, Vaughn JE (1989) Regulation of choline acetyltransferase. Int Rev Neurobiol 31:81-143.

Sambrook J, Fritsch EF, Maniatis T (1989) Molecular cloning: a laboratory manual, 2d ed. Cold Spring Habor, NY: Cold Spring Harbor Laboratory.

Scholnick S, Bray SJ, Morgan BA, McCormick CA, Hirsh J (1986) Distinct central nervous system and hypoderm regulatory elements of the D. melanogaster dopa decarboxylase gene. Science 234:9981002 .

Schotzinger RJ, Landis SC (1990) Acquisition of cholinergic and peptidergic properties by sympathetic innervation of rat sweat glands requires interaction with normal target. Neuron 5:91-100.

Simon JA, Lis JT (1987) A germline transformation analysis reveals flexibility in the organization of heat shock concensus elements. $\mathrm{Nu}$ cleic Acid Res 15:2971-2988.
Slemmon JR (1989) Sequence analysis of a proteolyzed site in Drosophila choline acetyltransferase. J Neurochem 52:1898-1904.

Slemmon JR, Salvaterra PM, Crawford GD, Roberts E (1982) Purification of choline acetyltransferase from Drosophila melanogaster. J Biol Chem 257:3847-3852.

Sugihara H, Andrisani V, Salvaterra PM (1990) Drosophila choline acetyltransferase uses a non-AUG initiation codon and full length RNA is inefficiently translated. J Biol Chem 265:21714-21719.

Sugihara H, Andrisani V, Salvaterra PM (1991) Genomic organization of the Drosophila choline acetyltransferase gene. J Neurochem 57: 1636-1642.

Sulston JE, Horwitz HR (1977) Post-embryonic cell lineages of the nematode Caenorhabditis elegans. Dev Biol 82:41-55.

Tajima Y, Salvaterra PM (1990) Sequence of choline acetyltransferase temperature-sensitive mutants determined by the polymerase chain reaction. Neuroscience 39:245-250.

Thummell CS, Boulet AM, Lipshitz HD (1988) Vectors for Drosophila P-element-mediated transformation and tissue culture transfection. Gene 74:445-456.

Yamamori T, Fukada K, Aebersold R, Korsching S, Fann MJ, Patterson PH (1989) The cholinergic neuronal differentiation factor from heart cells is identical to leukemia inhibitory factor. Science 246:14121416 . 